\title{
Terrain Ruggedness and Caribou Forage Availability during Snowmelt on the Arctic Coastal Plain, Alaska
}

\author{
CHRISTIAN NELLEMANN $^{1}$ and METTE GOUL THOMSEN ${ }^{2}$
}

(Received 9 June 1993; accepted in revised form 7 July 1994)

\begin{abstract}
This paper reports a close link between terrain ruggedness and forage availability for caribou during snowmelt. Indices of terrain ruggedness based on contour characteristics from topographical maps were related to field measures of cover, biomass, and live/dead ratio of graminoids within the Kuparuk Oilfield, Alaska. Terrain ruggedness was found to be the most significant factor affecting forage availability during snowmelt within the study area. Terrain ruggedness was positively correlated to 1) graminoid cover within wet, moist and dry herbaceous tundra, 2) cover of four individual graminoid species, 3) height of Salix planifolia, 4) amount of Eriophorum vaginatum flowers, and 5) live/dead ratio of plant material during early and late snowmelt. The live/dead ratio of plant material varied among vegetation types during snowmelt, causing rugged areas to have sprouting green plant material available for forage throughout this period. While annual differences in snow depths and snowmelt will affect forage availability in a given year, indices of terrain ruggedness combined with vegetation maps can substantially improve our understanding of how forage availability for caribou may vary across the landscape during snowmelt.
\end{abstract}

Key words: Alaska, caribou forage, spring, topography, vegetation.

RÉSUMÉ. Cet article rapporte le lien étroit qui existe entre le caractère accidenté du terrain et la disponibilité d'herbage pour le caribou durant la fonte nivale. On a relié les indices d'aspérité du terrain déterminés par les caractéristiques des courbes de niveaux sur les cartes topographiques aux mesures sur le terrain du tapis, de la biomasse et du rapport de graminées vivantes aux graminées mortes dans le champ pétrolifère Kuparuk en Alaska. On a trouvé que l'aspérité du terrain était le facteur le plus important affectant la disponibilité d'herbage durant la fonte nivale dans la zone d'étude. L'aspérité du terrain était corrélée de façon positive 1) au couvert de graminées de la toundra herbacée saturée d'eau, humide et sèche, 2) au couvert de quatre espèces individuelles de graminées, 3) à la hauteur de Salix planifolia, 4) à la quantité de fleurs de Eriophorum vaginatum et 5) au rapport du matériau végétal vivant au matériau végétal mort au début et à la fin de la fonte nivale. Le rapport de ces deux sortes de matériau végétal variait parmi les types de végétation durant la fonte nivale, ce qui faisait que les zones accidentées avaient de nouvelles pousses de matériau végétal disponibles comme herbage durant toute cette période. Bien que les différences d'une année à l'autre dans l'épaisseur de la neige et dans la fonte nivale aient des répercussions sur la disponibilité d'herbage au cours d'une année donnée, des indices de l'aspérité du terrain combinés aux cartes de végétation peuvent nous aider considérablement à comprendre comment la disponibilité d'herbage pour le caribou peut varier dans tout le territoire au cours de la fonte nivale.

Mots clés: Alaska, alimentation du caribou, printemps, topographie, végétation

Traduit pour la revue Arctic par Nésida Loyer.

\section{INTRODUCTION}

Selection of the calving grounds by barren-ground caribou (Rangifer tarandus granti) is believed to depend upon many factors of which tradition, forage availability and predator avoidance are hypothesized to be important (Bergerud and Page, 1987; Eastland et al., 1989; Fancy and Whitten, 1991). On the Arctic Coastal Plain of Alaska, calving normally takes place in June during snowmelt (Cameron et al., 1992). The location of the calving grounds may vary among years, but generally takes place on the coastal plain to reduce exposure of calves to predation (Fancy and Whitten, 1991). Within the coastal plain, calving appears to be concentrated in areas of patchy snowmelt, possibly because emerging nutritious vegetation is available (Eastland et al., 1989). However, areas with patchy snow cover may extend over considerable ranges in spring, and little is known about how forage availability may vary within such areas. The potential calving grounds may cover several thousand square kilometers; thus, traditional field-based vegetation sampling becomes logistically problematic and expensive. In recent years, satellite imagery has been used to map at a relatively coarse scale the distribution of vegetation (Walker and Acevedo, 1987) and potential forage available for ungulates (Pearce, 1991). Plant growth in spring is locally affected by the combined actions of snowmelt, microclimate, drainage and soil development, and those factors in turn are affected by topographic relief. The analysis of terrain structure should therefore provide a simple means of analyzing differences in plant phenology and biomass even within vegetation types.

In this study, we compared indices of terrain ruggedness with

\footnotetext{
${ }^{1}$ Department of Biology and Nature Conservation, Agricultural University of Norway, P.O. Box 5014, N-1430 Ås-NLH, Norway

${ }^{2}$ Norwegian Forest Research Institute, Høgskoleveien 12, N-1430 Ås, Norway

(C) The Arctic Institute of North America.
} 
measures of available forage throughout the snowmelt period to test whether terrain ruggedness influenced forage availability and to develop a simple method suitable to help determine caribou forage availability during snowmelt.

\section{STUDY AREA}

Data were collected in a portion of the calving grounds of the Central Arctic Caribou Herd within the Kuparuk Oilfield, situated in the central part of the Arctic Coastal Plain in northern Alaska $\left(70^{\circ} 30^{\prime} \mathrm{N}, 149^{\circ} 00^{\prime} \mathrm{W}\right)$ (Fig.1). The study area included a 30 by $30 \mathrm{~km}$ section of the calving grounds near the coast approximately $45 \mathrm{~km}$ west of Prudhoe Bay, on the west side of the Kuparuk River. The study area is a typical thermokarst landscape dominated by thaw lakes (Walker, 1985), and topographic relief occurs mainly as the result of various frost-related phenomena. Occasional pingos and both low-and high-centered polygons contribute to the relief. Total relief is modest: elevations seldom exceed $20 \mathrm{~m}$ above sea level. The local relief, however, still allows for clear gradients in snow pattern and soil moisture, thus causing considerable variation in the characteristics and distribution of plant communities (Walker et al., 1980; Shaver et al., 1990).

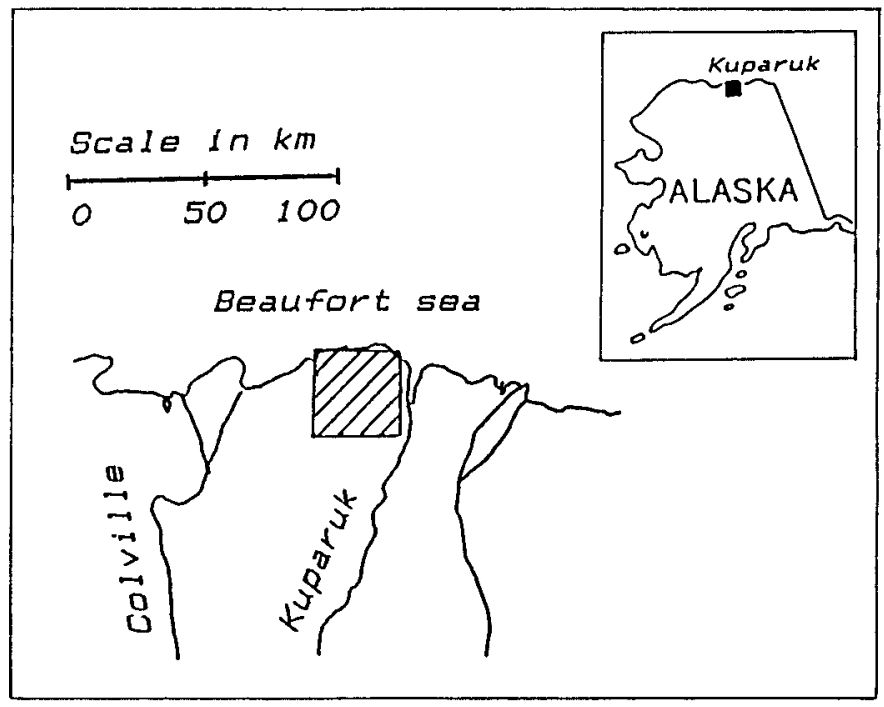

FIG. 1. The location of the study area within the Kuparuk Oilfield on the Arctic Coastal Plain of Alaska.

\section{METHODS}

Fieldwork was performed between late May and late June 1992, a period which covered the onset of snowmelt and extended two weeks after snowmelt. Within the study area 21 sites, each $2.25 \mathrm{~km}^{2}$, were selected randomly for sampling.

A simple index of terrain ruggedness based on topographical maps (USGS 1:63,360) with contour intervals of $15.5 \mathrm{~m}$ was used for the terrain analysis. The index estimated terrain ruggedness at a mesoscale level, including surface structures ranging in size from 10 to $20 \mathrm{~m}$, such as bluffs, hollows and smaller drainages as defined by Chernov (1985). The index was calculated by placing one $2 \mathrm{~km}$ long transect across the center of each $2.25 \mathrm{~km}^{2}$ site. The transect was placed so that it crossed the greatest variation in relief possible. The index of terrain ruggedness was based on the total number of contour lines (TNC) intercepted along the transect, and the total number of fluctuations (TNF) encountered along the same transect (Fig. 2). The TNF in terrain surface is defined by the number of separate aspects resulting from the occurrence of anti- and synclinals along the transect. An area with considerable change in relief (many anti-/synclinals) and many contour intercepts will thus have high values of ruggedness, while smooth terrain will receive low values. To reduce the effect of extreme values of either component on index values, the following equation was used to calculate the index:

\section{Terrain Ruggedness Index $=(\mathrm{TNC} \times \mathrm{TNF})(\mathrm{TNC}+\mathrm{TNF})^{-1}$}

Within each site, vegetation characteristics were measured in ten plots $\left(1 \mathrm{~m}^{2}\right)$ placed at $100 \mathrm{~m}$ intervals along the transects used to estimate terrain ruggedness on the maps. The position of the first plot along the transect was randomly selected. A total of 420 plots were measured.

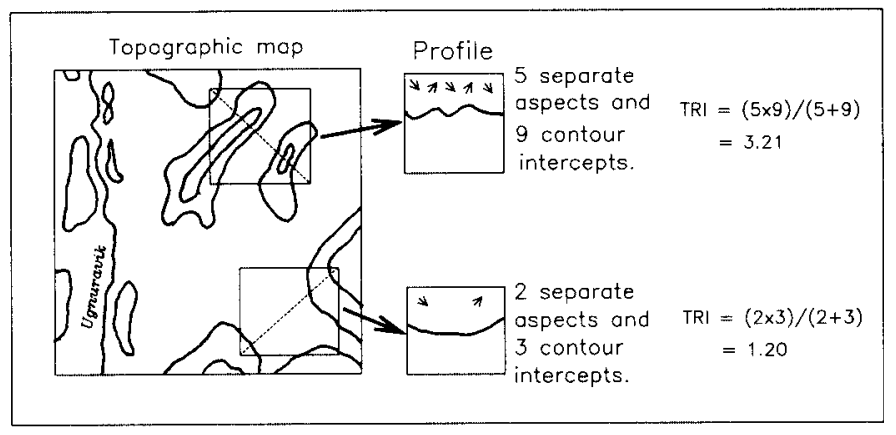

FIG. 2. The calculation of terrain ruggedness indices from a topographic map (See text).

Within each plot, total graminoid cover and cover of four dominant graminoid species (Carex aquatilis, C. bigelowii, Eriophorum vaginatum, and E. angustifolium) were recorded. The number of stems $/ \mathrm{m}^{2}$ and height $(\mathrm{dm})$ were also recorded for Salix planifolia. These five species are all forage species for caribou (White and Trudell, 1980; Klein, 1990). Cover was measured by counting the number of cells $(10 \times 10 \mathrm{~cm})$ with more than $50 \%$ graminoid cover out of 100 cells in each $1 \mathrm{~m}^{2}$ plot, according to Wratten and Fry (1980). To determine the relationship between total graminoid cover and biomass, the vegetation on 25 randomly chosen plots was clipped, dried and weighed.

Forage quality also was indexed by a measure of phenological progress given as the live/dead ratio of plant material. The amount of live and dead material on the grass leaf was measured in percent of total leaf length (from culm to tiller) on ten random leaves in one center and four corner 10 by $10 \mathrm{~cm}$ cells in all 420 of the $1 \mathrm{~m}^{2}$ vegetation plots. Measurement of the live/dead ratio of plant material was done in two snowmelt periods to determine potential differences in the percentage of available green forage 

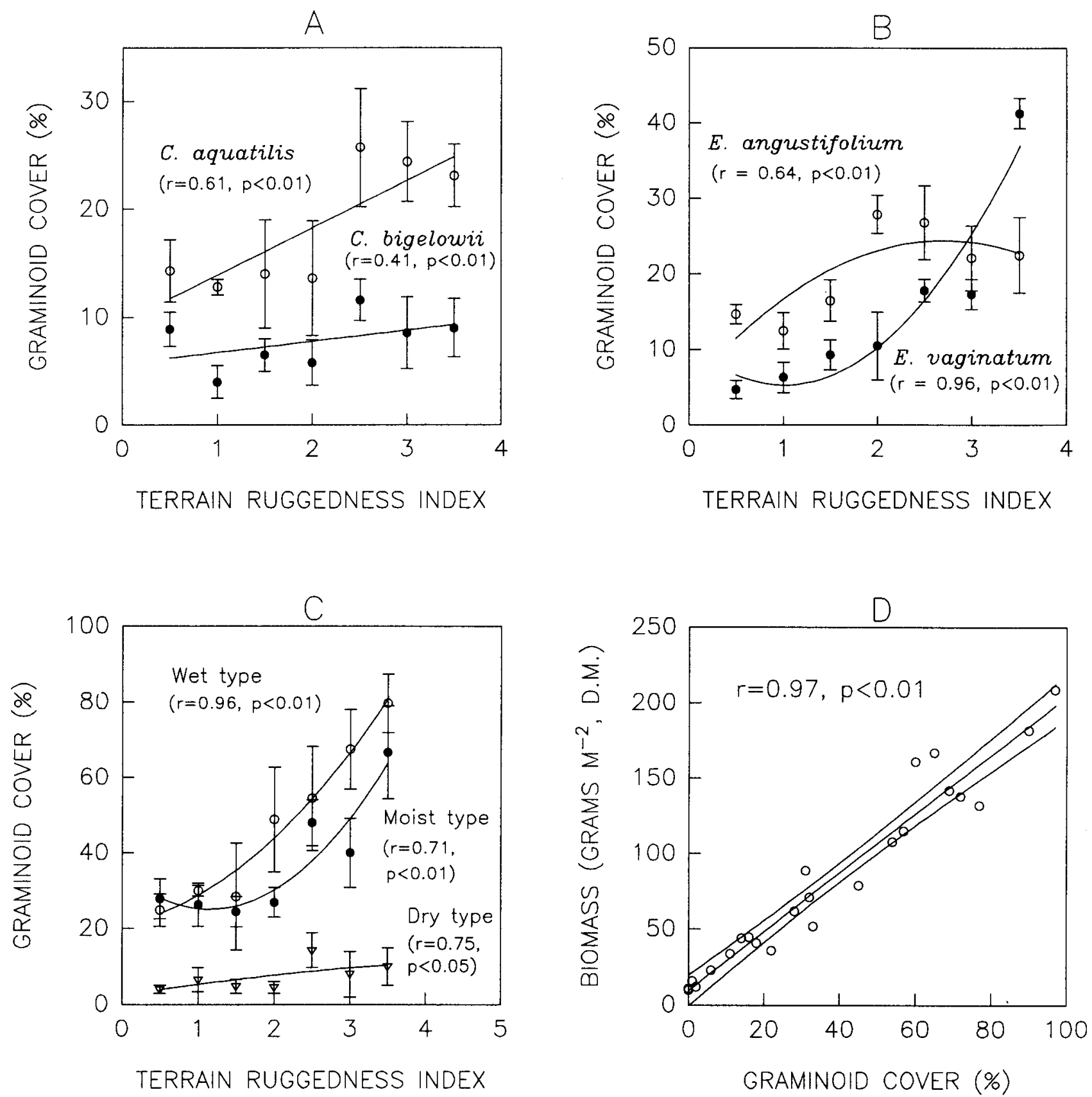

FIG. 3a-d. The relationship between terrain ruggedness indices and graminoid cover for a) two Carex species, b) two Eriophorum species, and c) three vegetation types. The relationship between cover estimates and biomass (grams dry matter $/ \mathrm{m}^{2}$ ) is given in (d). Standard errors are shown for $(\mathrm{a}-\mathrm{c}$ ) and a $95 \%$ confidence interval for (d). Vegetation analysis was conducted within the Kuparuk Oilfield on the Arctic Coastal Plain, Alaska 1992.

between vegetation types throughout the snowmelt period. The first period covered one week in late May, when snow cover was estimated to be approximately $50 \%$, and the same transects were revisited in the late-snowmeltperiod in mid June, when snowcover was $<5 \%$. The emergent Eriophorum vaginatum and $E$. angustifolium flowers were counted within all plots at each site (White and Trudell, 1980). The phenological stage of flowers was recorded in two groups: 1) flowers without visible stamen, 2) flowers with visible stamen and older.

The frequency of three major vegetation types in each site was obtained by classifying each individual plot along the transect as either dry herbaceous tundra (dominated by Dryas sp.), moist herbaceous tundra (dominated by Eriophorum spp.), or wet herbaceous tundra (dominated by Carex aquatilis). This was done to avoid bias on cover estimates resulting from differences in the frequency of the major vegetation types in different terrain, as well as to determine a potential relationship between terrain ruggedness and vegetation distribution.

Microtopographic diversity (Chernov, 1985) was estimated by measuring the horizontal distance of a $3 \mathrm{~m}$ long chain laid on the ground at each vegetation plot in a straight, but random direction. The shorter the distance, the higher the variation in topography at this microscale. The inverse of the distance was calculated to derive an index of microtopographic diversity (Chernov, 1985). 
To avoid bias resulting from differences in vegetative characteristics and snowmelt from coast to inland (Walker, 1985), one site with high and one site with low terrain ruggedness, approximately an equal distance from the coast, were sampled each day. High and low were defined by the upper and lower 50th percentile of the frequency distribution of sites on terrain ruggedness. Within each group the sites were selected randomly.

Statistical analysis was done in SIGMASTAT, and assessments of vegetative characteristics associated with degree of terrain ruggedness were done using Spearman's coefficient of rank correlation. For this purpose, the 21 sites were divided into 7 classes of terrain ruggedness ( $\mathrm{n}=3$ sites in each class). Prior to any test, we conducted a Kolmogorov-Smirnov test of normality. Kruskal-Wallis ANOVA with Dunn's test was used for comparing cover estimates among individual vegetation types, and for comparing the live/dead ratio of plant material among vegetation types and snowmelt periods. Multiple regression analysis was used to determine the significance of terrain ruggedness, microtopographic diversity, vegetation distribution (percentage of plots in each vegetation type in each site) and distance $(\mathrm{km})$ to coast for variation in cover and in the live/dead ratio of plant material among the 21 sites. The "Behrens-Fisher problem" of unequal sample variances was assessed by adjusting degrees of freedom according to Davenport and Webster (1975). Probability $(p)$ values $<0.05$ were considered statistically significant.

\section{RESULTS}

Total graminoid cover was positively correlated to terrain ruggedness $(\mathrm{r}=0.82, p<0.05)$. Graminoid cover of all the individual species assessed increased significantly in rugged terrain (Fig. 3a,b), particularly for E. vaginatum (Fig. 3b). Graminoid cover increased in rugged terrain within all three individual vegetation types (Fig. 3c). The estimates of graminoid cover were highly correlated to biomass measured (d.m. $\left.\mathrm{m}^{-2}\right)(\mathrm{r}$ $=0.97, p<0.01)$ (Fig. 3d). Terrain ruggedness was also correlated to the number of Salix planifolia stems $/ \mathrm{m}^{2}(\mathrm{r}=0.75, p<$ $0.01)$ and to the percentage of stems higher than $10 \mathrm{~cm}(\mathrm{r}=0.61$, $p<0.01$ ). Cover of individual species and vegetation types is given in Table 1 . Cover was generally lowest $(p<0.05)$ in dry herbaceous tundra (Table 1), and highest in wet herbaceous tundra (Fig. 3c).

The density of $E$. vaginatum flowers (number $/ \mathrm{m}^{2}$ ) within moist herbaceous tundra increased in rugged terrain (Fig. 4). Flowers of this species in early stages of growth were most abundant early in the snowmelt period (Table 2). Flowering of E. angustifolium within wet herbaceous tundra primarily started at the end of the snowmelt period (Table 2), and had only begun in six sites in late June. For these sites, density of flowers increased with ruggedness of terrain $(\mathrm{r}=0.87, p<0.05)$. Heavy browsing by caribou was observed on these flowers. No flowers of Carex spp. were observed during the snowmelt period.

The live/dead ratio of plant material was positively correlated to terrain ruggedness during the early snowmelt period $(\mathrm{r}=0.79$, $p<0.01)$ and late snowmelt period $(\mathrm{r}=0.56, p<0.01)$.
Considerable variation in the live/dead ratio of plant material among the three vegetation types also was found in these two periods. During the first part of the snowmelt period, moist herbaceous tundra had a significantly higher $(p<0.05)$ percentage of green plant material than dry and wet herbaceous tundra (Table 2). Following snowmelt, wet herbaceous tundra rapidly turned green. This vegetation type therefore had the highest percentage of available green plant material at the end of snowmelt (Table 2).

Rugged areas were also found to have consistently greater microtopographic diversity, as measured by the "chain" method $(\mathrm{r}=0.89, p<0.01)$.

Terrain ruggedness accounted for most of the variation in total graminoid cover among the 21 sites $\left(\mathrm{r}^{2}=0.47, p<0.001\right.$, multiple regression). Terrain ruggedness also was the best explanatory variable when the live/dead ratio of plant material was compared for the 21 sites $\left(r^{2}=0.69, p<0.001\right.$, multiple regression). Vegetation distribution, coastal distance and microtopographic diversity were not significant factors in explaining the variation among sites in cover or the live/dead ratio of plant material.

Table 1. Vegetation cover (mean \pm SE) of selected graminoids and Salix planifolia in different vegetation types within the Kuparuk Oilfield, Alaska 1992.

\begin{tabular}{|c|c|c|c|c|c|c|}
\hline \multirow[b]{3}{*}{ C. aquatilis } & \multicolumn{6}{|c|}{ Vegetation types (\% cover) } \\
\hline & \multicolumn{2}{|l|}{ Dry } & \multicolumn{2}{|l|}{ Moist } & \multicolumn{2}{|l|}{ Wet } \\
\hline & $\approx 0$ & a & $4.3 \pm 1.3$ & $\mathrm{~b}$ & $22.2 \pm 3.2$ & $\mathrm{c}$ \\
\hline C. bigelowii & $1.3 \pm 0.5$ & $\mathrm{~d}$ & $3.7 \pm 0.6$ & $\mathrm{~b}$ & $1.9 \pm 0.6$ & $\mathrm{~d}$ \\
\hline E. vaginatum & $2.4 \pm 1.2$ & bd & $6.3 \pm 1.0$ & $\mathrm{e}$ & $\approx 0$ & $\mathrm{e}$ \\
\hline E. angustifolium & $2.2 \pm 1.1$ & bd & $18.8 \pm 2.2$ & $\mathrm{cf}$ & $15.7 \pm 3.2$ & ef \\
\hline Other graminoids & $0.6 \pm 0.3$ & $\mathrm{~d}$ & $5.8 \pm 1.0$ & e & $\approx 0$ & $\mathrm{a}$ \\
\hline Total & $6.5 \pm 1.5$ & be & $39.0 \pm 2.3$ & g & $38.3 \pm 3.9$ & $\mathrm{~g}$ \\
\hline S. planifolia $\left(\mathrm{stems} / \mathrm{m}^{2}\right)$ & $2.1 \pm 0.9$ & bd & $2.5 \pm 0.4$ & $\mathrm{~b}$ & $1.2 \pm 0.3$ & bd \\
\hline Percentage stems $>10 \mathrm{~cm}$ & $\approx 0$ & $\mathrm{a}$ & $25.0 \pm 7.0$ & $\mathrm{cf}$ & $45.0 \pm 13.0$ & $\mathrm{~h}$ \\
\hline
\end{tabular}

Different letters indicate a significant difference $(p<0.05)$ using Kruskal-Wallis ANOVA with Dunn's test.

\section{DISCUSSION}

Our analysis of terrain ruggedness correlated well with a number of forage characteristics within the study area. The higher biomass and higher live/dead ratio of plant material in rugged areas are likely caused by more favourable conditions for plant growth in such terrain during early summer. Such conditions include higher air and soil temperatures, and greater thaw depths, water drainage, moisture and nutrient availability (Billings, 1987), all affected by topographic relief.

An earlier and more rapid snowmelt will take place on windblown anticlinals because there is less snow, and on southfacing slopes in rugged areas, which receive more radiation than flat areas. Rugged areas will also have relatively deep snow accumulated in synclinals during winter, causing these areas to have not only the first available snowfree areas on windblown 
Table 2. Live/dead ratio of graminoid plant material and density of Eriophorum flowers (mean \pm SE) during early ( $>50 \%$ snow cover) and late snowmelt (<5\% snow cover) within the Kuparuk Oilfield, Alaska 1992.

\begin{tabular}{|c|c|c|c|c|c|c|c|c|c|c|c|c|}
\hline & \multicolumn{5}{|c|}{$\begin{array}{c}\text { Early Snowmelt Period } \\
\text { Vegetation Type }\end{array}$} & & \multicolumn{5}{|c|}{$\begin{array}{c}\text { Late Snowmelt Period } \\
\text { Vegetation Type }\end{array}$} & \\
\hline & Dry & & Moist & & Wet & & Dry & & Moist & & Wet & \\
\hline Live/dead ratio of plant material & $6.0 \pm 0.9$ & $\mathrm{a}$ & $12.5 \pm 0.6$ & $\mathrm{~b}$ & $8.6 \pm 0.9$ & $\mathrm{c}$ & $35.9 \pm 3.7$ & $\mathrm{~d}$ & $39.3 \pm 1.7$ & $\mathrm{~d}$ & $63.4 \pm 3.0$ & $\mathrm{e}$ \\
\hline E. vaginatum flowers $\left(\mathrm{no} / \mathrm{m}^{2}\right)$ & $1.7 \pm 1.5$ & $\mathrm{a}$ & $3.7 \pm 0.9$ & $\mathrm{~b}$ & $\approx 0$ & $\mathrm{c}$ & $1.4 \pm 1.3$ & $\mathrm{a}$ & $3.6 \pm 1.4$ & $\mathrm{~b}$ & $\approx 0$ & $\mathrm{c}$ \\
\hline$\%$ of flowers without visible stamen & $9.4 \pm 6.6$ & $\mathrm{a}$ & $55.1 \pm 12.1$ & $\mathrm{~b}$ & $\approx 0$ & $\mathrm{c}$ & $\approx 0$ & $\mathrm{c}$ & $21.8 \pm 7.6$ & $\mathrm{a}$ & $\approx 0$ & $\mathrm{c}$ \\
\hline E. angustifolium flowers $\left(\mathrm{no} / \mathrm{m}^{2}\right)$ & $\approx 0$ & $\mathrm{c}$ & $\approx 0$ & $\mathrm{c}$ & $\approx 0$ & $\mathrm{c}$ & $0.4 \pm 0.4$ & $\mathrm{a}$ & $0.4 \pm 0.2$ & $\mathrm{a}$ & $2.7 \pm 0.9$ & $\mathrm{~b}$ \\
\hline$\%$ of flowers without visible stamen & $\approx 0$ & $\mathrm{c}$ & $\approx 0$ & $\mathrm{c}$ & $\approx 0$ & $\mathrm{c}$ & $83.3 \pm 16.6$ & $\mathrm{~d}$ & $74.3 \pm 10.6$ & $\mathrm{~d}$ & $34.9 \pm 11.7$ & $\mathrm{~b}$ \\
\hline
\end{tabular}

Different letters indicate a significant difference (within row), $p<0.05$, using Kruskal-Wallis ANOVA with Dunn's test.

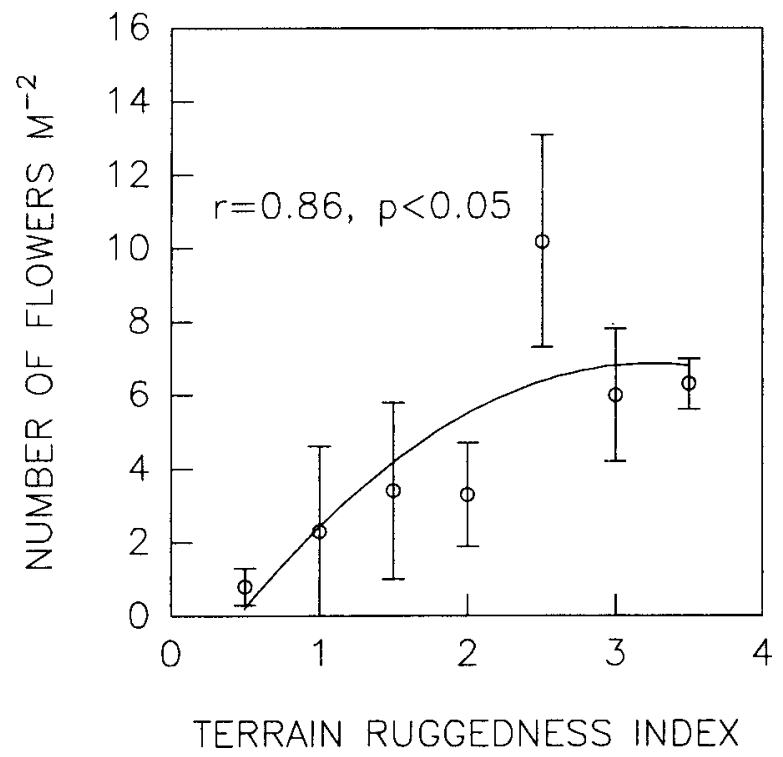

FIG. 4. Density of Eriophorum vaginatum flowers (number/ $\mathrm{m}^{2}$ ) within moist herbaceous tundra observed in different terrain types given as indices of terrain ruggedness. Standard errors are shown. Vegetation analysis was conducted within the Kuparuk Oilfield on the Arctic Coastal Plain, Alaska 1992.

anticlinals, but also very patchy snowmelt, prolonging the snowmelt period.

The higher microtopographic diversity associated with rugged areas may provide a better microclimate for plant growth by increasing soil temperatures, resulting in enhanced budding of $E$. vaginatum (Chapin et al., 1979; Eastland et al., 1989). The flowers are considered an important nutrient source for calving caribou (White and Trudell, 1980). The higher microtopographic diversity was generally the result of more tussocks, hummocks and high-centered polygons. Areas with low terrain ruggedness also occasionally had these features along with frost boils and low-centered polygons, but their contribution to overall microtopographic diversity was not sufficient to compensate for the large smooth Dryas terraces and low-lying C. aquatilis meadows dominating these areas.

Thaw of the active layer above the permafrost should occur earlier on anticlinals and slopes in rugged areas than in smoother terrain, at similar distances from the coast. Early thaw of the active layer will promote water drainage and thus increase soil temperature and nutrient availability for plants (Murray and
Miller, 1982; Billings, 1987; Matthes-Searset al., 1988). Growth of graminoids in the Arctic has been shown to be limited particularly by nitrogen, and to some extent by phosphorous (Shaver and Chapin, 1986; Billings, 1987). Increased nutrient availability, rather than length of the snowfree season, may partly explain higher plant production related to rugged terrain (Miller, 1982; Murray and Miller, 1982). In summary, the higher availability of caribou forage in rugged terrain is presumably due to the many south-facing slopes with protective snow cover in winter, rapid snowmelt on exposed anticlinals in spring, favourable moisture throughout the summer, higher soil temperatures and possibly relatively high nutrient availability (Walker et al., 1980; Matthes-Sears et al., 1988; Shaver et al., 1990).

Shallow snowmelt ponds dominated by E. angustifolium appeared to turn green rapidly, although this process occurred much later than for graminoids in more elevated areas. This was likely due to the low albedo in such ponds, which caused them to heat rapidly when thawed. This rapid increase in the live/dead ratio of plant material caused the wet vegetation types to become the greenest at the end of the snowmelt period. Although lowlying flat areas also turned green rapidly following snowmelt, total cover and biomass remained low, possibly because of an overall nutrient deficiency caused by slow water drainage (Matthes-Sears et al., 1988).

Within the study area, terrain ruggedness appeared more important for plant production than coastal distance. Temperatures on the coastal plain generally increase with distance from the coast (Walker et al., 1980), suggesting more favourable plant growth conditions farther inland. Distances to the coast from individual sites ranged from 1.6 to $21 \mathrm{~km}$, but flat low-productive sites were found not only in the outer $0-2 \mathrm{~km}$ from the coast, but also far inland, suggesting that this factor was of relatively low importance to forage availability. The number of sites was too small for comparing cover with coastal distances within single terrain classes.

Terrain ruggedness was also found to be more important for total plant production than general vegetation distribution. While graminoid cover clearly was lowest in dry herbaceous tundra, and only minor increases for this vegetation type were observed in rugged terrain, cover increased considerably in rugged terrain for moist and wet types (Fig. 3c, Table 1). These results indicate that if rugged areas tend to have higher plant production, even within individual vegetation types, then the index of terrain 
ruggedness cannot be replaced by vegetation maps alone. Inaccuracy of remotely sensed information on snow or vegetation distribution is also highest in more rugged terrain (Hall et al., 1991). Vegetation maps should therefore be supplemented with indices of terrain ruggedness to provide better information on how plant characteristics may vary across the landscape.

The implication of higher plant production in rugged terrain for caribou is an increased availability of forage in such areas during snowmelt (Eastland et al., 1989). Anticlinals in rugged terrain were the first areas to provide green sprouting plant material for forage. Seen in combination with the high diversity of vegetation types caused by the variation in topographic relief, rugged areas generally supplied more emerging Eriophorum flowers for a longer period than smooth terrain (Table 2, Fig. 4), as hypothesized by Eastland et al. (1989). Moist vegetation types had the highest percentage of green forage early in the snowmelt period. However, wet vegetation types turned green rapidly at the end of the snowmelt period, causing wet vegetation to have the highest live/dead ratio of plant material following snowmelt (Table 2). A high variability of vegetation types within short horizontal distances in rugged terrain (Shaver et al., 1990) will enable herbivores to follow plant phenology easily within short distances (Skogland, 1980; Thing, 1984; Klein, 1990). Thus, caribou can utilize lichen and $E$. vaginatum flowers on bluffs and slopes early in snowmelt, and mosses and E. angustifolium flowers in low-lying terrain at the end of the snowmelt period. Pregnant caribou cows may have a contracted rumen and thus a reduced intake of forage (Hofmann, 1985), which makes the availability of emerging $E$. vaginatum flowers an important nutrient source, although the biomass of these flowers is low (White and Trudell, 1980). The higher forage biomass, higher availability of Eriophorum flowers, and higher variability in vegetation types in rugged areas within an otherwise "flat" coastal plain during snowmelt should be of considerable interest to herbivore researchers with regard to habitat and calving ground selection of caribou.

The index of terrain ruggedness appeared to correspond well with forage availability during snowmelt. However, annual variation in timing of snowmelt determines which areas will provide available forage for calving caribou within a given year. In years with very early snowmelt, more forage will likely be available in wet vegetation types (Tables 1,2 ), whereas in years of late snowmelt, forage will be available only on exposed, windblown anticlinals. While calving generally is located away from the foothills to avoid predation (Fancy and Whitten, 1991), the exact location on the coastal plain may vary. Eastland et al. (1989) found that caribou generally selected areas with patchy snowmelt for calving, the location of which varied annually dependent upon timing of snowmelt. However, within such areas of patchy snowmelt, the results presented here clearly suggest greater forage availability in relatively rugged terrain compared to other parts of the coastal plain. It remains uncertain to what degree terrain ruggedness can affect predator avoidance, although Skogland (1984) noted that rugged areas could be important in this context. In spite of the limitations caused by varying snowmelt patterns in different years, indices of terrain ruggedness can aid in identifying areas that generally will have higher forage availability over a longer period.

\section{ACKNOWLEDGEMENTS}

We thank Dr. W.T. Smith for assistance and Dr. D.R. Klein and Dr. R.D.Cameron for use of the field station in Kuparuk. We also thank Torre Jorgenson and two anonymous referees for reviewing the manuscript, and Kuparuk Industrial Center for their hospitality.

\section{REFERENCES}

BERGERUD, A.T., and PAGE, R.E. 1987. Displacement and dispersion of parturient caribou as antipredator tactics. Canadian Journal of Zoology 65:1597-1606.

BILLINGS, W.D. 1987. Constraints to plant growth, reproduction, and establishment in arctic environments. Arctic and Alpine Research 19:357-365.

CAMERON, R.D., REED, D.J., DAU, J.R., and SMITH, W.T. 1992. Redistribution of calving caribou in response to oil field development on the Arctic Slope of Alaska. Arctic 45:338-342.

CHAPIN, F.S., VAN CLEVE, K., AND CHAPIN, M.C. 1979. Soil temperature and nutrient cycling in the tussock growth form of Eriophorum vaginatum. Journal of Ecology 67:169-189.

CHERNOV, Y.I. 1985. The living tundra. Cambridge: Cambridge University Press. 213 p.

DAVENPORT, J.M., and WEBSTER, J.T. 1975. The Behrens-Fisher problem, an old solution revisited. Metrika 22:47-54. Cited in Zar, J.H. 1984. Biostatistical analysis. Englewood Cliffs, New Jersey: Prentice Hall.

EASTLAND, W.G., BOWYER, R.T., and FANCY, S.G. 1989. Caribou calving sites relative to snowcover. Journal of Mammalogy 70:824-828.

FANCY, S.G., and WHITTEN, K.R. 1991. Selection of calving sites by Porcupine Caribou herd. Canadian Journal of Zoology 69:1736-1743.

HALL, D.K., STURM, M., BENSON, C.S., CHANG, A.T.C., FOSTER, J.L., GARBEIL, H., and CHACHO, E. 1991. Passive microwave remote and in situ measurements of arctic and subarctic snow covers in Alaska. Remote Sensing Environment 38:161-172.

HOFMANN, R.R. 1985. Digestive physiology of deer-Their morphophysiological specialisation and adaptation. In: Fennessy, P.F., and Drew, K.R., eds. Biology of deer production. The Royal Society of New Zealand, Bulletin 22:393-407.

KLEIN, D.R. 1990. Variation in quality of caribou and reindeer forage plants associated with season, plant part and phenology. Rangifer Special Issue 3:123-130.

MATTHES-SEARS, U., MATTHES-SEARS, W.C., HASTINGS, S.J., and OECHEL, W.C. 1988. The effects of topography and nutrient status on the biomass, vegetative characteristics, and gas exchange of two deciduous shrubs on an arctic tundra slope. Arctic and Alpine Research 20:342-351.

MILLER, P.C. 1982. Environmental and vegetational variation across a snow accumulation area in montane tundra in central Alaska. Holarctic Ecology 5:85-98. 
MURRAY,C., and MILLER, P.C. 1982. Phenological observations of major plant growth forms and species in montane and Eriophorum tussock tundra in central Alaska. Holarctic Ecology 5:109-116.

PEARCE, C.M. 1991. Mapping muskox habitat in the Canadian High Arctic with SPOT satellite data. Arctic 44 (Supp. 1):49-57.

SHAVER, G.R., and CHAPIN, F.S. 1986. Effect of fertilizer on production and biomass of tussock tundra, Alaska, U.S.A. Arctic and Alpine Research 18:261-268.

SHAVER, G.R., NADELHOFFER, K.J., and GIBLIN, A.E. 1990. Biogeochemical diversity and element transport in a heterogenous landscape, the North Slope of Alaska. Ecological Studies 82: $105-125$.

SKOGLAND, T. 1980. Comparative summer feeding strategies of arctic and alpine Rangifer. Journal of Animal Ecology 49:81-98.

1984. Life history characteristics of wild reindeer (Rangifer tarandus tarandus) in relation to their food resources: Ecological effects and behavioral adaptations. Holarctic Ecology 7:345-379.
THING, H. 1984. Feeding ecology of the West Greenland Caribou (Rangifer tarandus groenlandicus) in the Sisimiut-Kangerlussuaq region. Danish Review of Game Biology 12:1-55.

WALKER, D.A. 1985. Vegetation and environmental gradients of the Prudhoe Bay region, Alaska. U.S. Army Corps of Engineers, CRREL Report 85/14:1-239.

WALKER, D.A., and ACEVEDO, W. 1987. Vegetation and a Landsatderived land cover map of the Beechey Point Quadrangle, Arctic Coastal Plain, Alaska. U.S. Army Corps of Engineers, CRREL Report 87/5.

WALKER, D.A., EVERETT, K.R., WEBBER, P.J., and BROWN, J. 1980. Geobotanical atlas of the Prudhoe Bay region, Alaska. U.S. Army Corps of Engineers, CRREL Report 80/14.

WHITE, R.G., and TRUDELL, J. 1980. Habitat preference and forage consumption by reindeer and caribou near Atkasook, Alaska. Arctic and Alpine Research 12:511-529.

WRATTEN, S.D., and FRY, G. 1980. Field and laboratory exercises in field ecology. London: Edward Arnold Publishers. 227 p. 